Discussion Paper No. 06-029

\title{
Innovation Activities Abroad and the Effects of Liability of Foreignness: Where it Hurts
}

Wolfgang Sofka

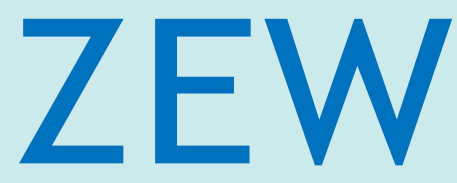

Zentrum für Europäische Wirtschaftsforschung $\mathrm{GmbH}$

Centre for European Economic Research 
Discussion Paper No. 06-029

\title{
Innovation Activities Abroad and the Effects of Liability of Foreignness: Where it Hurts
}

\author{
Wolfgang Sofka
}

Download this ZEW Discussion Paper from our ftp server:

ftp://ftp.zew.de/pub/zew-docs/dp/dp06029.pdf

Die Discussion Papers dienen einer möglichst schnellen Verbreitung von neueren Forschungsarbeiten des ZEW. Die Beiträge liegen in alleiniger Verantwortung der Autoren und stellen nicht notwendigerweise die Meinung des ZEW dar.

Discussion Papers are intended to make results of ZEW research promptly available to other economists in order to encourage discussion and suggestions for revisions. The authors are solely responsible for the contents which do not necessarily represent the opinion of the ZEW. 


\section{Non-technical summary}

Outsourcing and/or offshoring production and procurement has been a major theme of the globalization debate in recent years. Internationalizing $R \& D$ activities could be the logical next step. A growing stream of literature emerges that stresses the importance of harvesting creativity across the globe, which typically requires "being there." Foreign subsidiaries tap local pools of expertise and make them accessible for the multinational company (MNC). Hence, these innovation engagements of foreign subsidiaries can generate competitive advantage for the MNC as a whole.

To achieve this ambitious goal they need to become embedded in host country flows of valuable knowledge. While spatial proximity is almost a precondition, important cultural and social barriers remain. The literature has identified these frictional losses from operating out of the home market environment as "liability of foreignness" (Hymer, 1976; Zaheer, 1995). In this analysis we focus on these "stranger in a strange land" effects on the innovation activities of multinational corporations abroad. More precisely, we derive potential stumbling blocks during the innovation process conceptually, so that targeted management recommendations can be derived. We suggest that liability of foreignness may stifle innovation projects and lead to bad project choices and/or budget overruns. We test these hypotheses empirically for a large sample of roughly 1,000 firms with innovation activities in Germany.

We find that foreign innovation engagements do not stumble at the mobilization stages, but rather when projects have to be selected, planned and managed. We argue that multinational companies have no problems in spotting worthwhile innovation impulses abroad. The effects from a lack of local embeddedness kick in once these ideas have to be prioritized and aligned with resources. We suspect that project priorities and resource planning follow general guidelines of the multinational corporation. These shared procedures provide consistency within the MNC but limit the flexibility of foreign subsidiaries to bring their innovation initiatives fully in line with host country best practices. As a result they are more often forced to recalibrate projects or necessary resources. We build on these results to derive management recommendations for countervailing strategies. 


\title{
Innovation Activities Abroad and the Effects of Liability of Foreignness: Where it Hurts
}

\author{
Wolfgang Sofka
}

Centre for European Economic Research (ZEW), Mannheim, Germany

\begin{abstract}
The innovation activities of foreign subsidiaries have been identified as an important source of competitive advantage for multinational corporations. The success of these engagements depends heavily on tapping host country pools of localized expertise. To achieve this foreign subsidiaries have to overcome cultural and social barriers (liability of foreignness). We derive potential stumbling blocks in the innovation process theoretically and argue that these materialize as neglected projects, cancellations or budget overruns. We test these hypotheses empirically for more than 1,000 firms with innovation activities in Germany from various sectors. We find that foreign-controlled firms are not challenged by liability of foreignness at the project mobilization stage. The lack of local embeddedness becomes more binding as projects have to be prioritized and managed which we identify as more frequent mistakes and delays. We argue that this is the result of shared practices within the multinational firm that do not readily fit into the local context. Finally, we derive management recommendations how foreign innovation engagements can achieve similar levels of effectiveness and efficiency as host country competitors.
\end{abstract}

Keywords: Liability of foreignness, offshoring R\&D, internationalization, innovation management

JEL-Classification: F23, O31, O32, D83

Wolfgang Sofka

Sofka@zew.de

Phone: +49/621/1235-181, Fax: +49/621/1235-4181

Centre for European Economic Research (ZEW)

Department of Industrial Economics and International Management

P.O. Box 1034 43, D-68034 Mannheim, Germany

The author thanks Christian Rammer and Thorsten Teichert for invaluable comments and discussions. 


\section{$1 \quad$ Introduction}

So far the effects of globalization have been mostly experienced in the production and procurement segments of the value chain (Rugman and Verbeke, 2004). Now there appears to be a shift towards the companies' innovation activities and the opportunities from outsourcing and/or offshoring them. The World Investment Report (UNCTAD, 2005) features this emerging trend of internationalizing $R \& D$ activities. At the same time there is a growing stream of literature that stresses the importance of harvesting creativity across the globe, which typically requires "being there.” Foreign subsidiaries evolve through their innovation engagements from home-base exploiting towards increasingly home-base augmenting mandates (Birkinshaw and Hood, 1998; Kuemmerle, 1999). They tap local pools of expertise and make them accessible for the multinational company (MNC). Hence, these innovation engagements of foreign subsidiaries can generate competitive advantage for the MNC as a whole.

To achieve this ambitious goal they need to become embedded in host country flows of valuable knowledge. While spatial proximity is almost a precondition, important cultural and social barriers remain. The literature has identified these frictional losses from operating out of the home market environment as "liability of foreignness" (Hymer, 1976; Zaheer, 1995). In this analysis we focus on these "stranger in a strange land" effects on the innovation activities of multinational corporations abroad. More precisely, we derive potential stumbling blocks during the innovation process conceptually, so that targeted management recommendations can be derived. We suggest that liability of foreignness may stifle innovation projects and lead to bad project choices and/or budget overruns.

The existing research has largely relied on large MNCs or patent data ${ }^{1}$ which only documents successful innovations. We extend this literature by testing our conceptual framework on barriers to foreign innovation through survey data on more than 1,000 German firms and their innovation activities. Roughly ten percent of those are subsidiaries of foreign companies; within this setting we devise a trivariate probit estimation.

The analysis is structured as follows: Following this introduction, section 2 provides the conceptual framework which we develop further in the analytical section 3 to form hypotheses. Section 4 outlines the empirical study. The results of the estimation procedures are presented and discussed in section 5 while section 6 provides conclusions and management recommendations.

$1 \quad$ See for example Almeida and Kogut (1999), Almeida and Phene, (2004) or Jarillo and Martinez (1990). 


\section{Conceptual framework}

The traditional view on the innovation activities of multinational corporations regards the global headquarters as the centre of gravity for developing new technologies, with subsidiaries providing adaptation and cost efficiency (see for example Vernon (1966)). More recent research streams indicate that foreign subsidiaries play an elevated role as entities that generate competitive advantage for the multinational company (MNC) as a whole (Birkinshaw and Hood, 1998). Technology flows within MNCs are still important but the central role of foreign subsidiaries stems from their ability to tab into localized pools of expertise in the host country to provide technological and market information (Almeida and Phene, 2004). Several studies have shown that firms invest abroad to get the most out of these valuable resources (Anand and Delios, 2002; Anand and Kogut, 1997; Florida, 1997; Kuemmerle, 1999). Feinberg and Gupta (2004) show that the prospects of knowledge spillovers, from both host country factor endowments and competitors' R\&D investments, increase the attractiveness of foreign locations for $\mathrm{R} \& \mathrm{D}$. While this host country environment is important, it is not sufficient to generate competitive advantage. Foreign subsidiaries need to evolve over time and develop the necessary absorptive capacities to translate these external impulses into successful innovation (Birkinshaw and Hood, 1998). These capabilities to identify, assimilate and exploit valuable innovation inputs from the environment have to be developed in practice over time (Cohen and Levinthal, 1989, 1990). Foreign subsidiaries enable multinational companies to develop these competencies by engaging in local networks (Gulati et al., 2000) and benefiting from the regional mobility of skilled personnel (Almeida and Kogut, 1999). Hence, developing and strengthening interfirm and interpersonal relationships is a major part of foreign $R \& D$ engagements (Birkinshaw and Hood, 1998), the success of which is, in turn, crucial for generating competitive advantage.

Success in foreign innovation activities therefore depends heavily on becoming integrated in host country knowledge flows. Investing in foreign subsidiaries with R\&D responsibilities reduces the hampering effects from spatial distance but social, cultural, cognitive, administrative, institutional and organisational differences remain (Boschma, 2005; Ghemawat, 2001, 2003). The effects of the latter are especially challenging in the innovation process that relies heavily on tacit knowledge and face-to-face communication (Feinberg and Gupta, 2004).

The frictional losses stemming from this lack of embeddedness in the host country have been summarized as liability of foreignness (Hymer, 1976; Zaheer, 1995). The term implies that firms operating abroad encounter inevitable impediments that host country competitors do not. Hence, liability of foreignness is a relative concept. It comprises additional or disproportionably high cost as well as neglected revenue opportunities (Mezias, 2002a). These

disadvantages have four major drivers (Zaheer, 1995): Spatial distance (i.e. logistics, coordination, communication and monitoring across large distances and time zones), a lack of 
host country roots (i.e. higher learning costs), a perceived lack of host country legitimacy ${ }^{2}$ (i.e. higher reputation building costs) and restrictions from the home country (e.g. export constraints for high technology). These effects have been identified at various firm performance layers (e.g. profitability, growth, efficiency, exposure to labour lawsuits) and in several sectors (e.g. currency trading, banking, automobiles) (DeYoung and Nolle, 1996; Hasan and Hunter, 1996; Mezias, 2002b; Miller and Parkhe, 2002; Sofka and Zimmermann, 2005; Zaheer, 1995; Zaheer and Mosakowski, 1997; Zaheer and Zaheer, 1997). However, liabilities of foreignness are not the inevitable fate of every foreign engagement. Multinational firms can win these uphill battles through firm-specific advantages (Caves, 1971). What is more, continuous host country exposure and experience allows foreign companies to adjust and adapt while, at the same time, the host country environment gets used to the firm's presence (Petersen and Pedersen, 2002; Zaheer and Mosakowski, 1997). Still, management recommendations on how to overcome liabilities of foreignness remain scarce (Mezias, 2002a). We extend this existing literature by connecting the roots of liability of foreignness with a procedural perspective on the innovation process. In essence, we investigate at what stages of the process the effects of liability of foreignness are most prevalent, so that countervailing strategies can be targeted at these weak spots.

This aspect is probably best captured through the stream of marketing literature on country of origin effects. Several studies in this field find that customers use the information about a product's country of origin information as a cue for the expected product quality (see for example Diamantopoulos et al. (1995) or Hsieh (2004)), e.g. elegant Italian design or precise German engineering. For a review see Bilkey and Nes (1982). 


\section{$3 \quad$ Analytical framework}

\section{The roots of liability of foreignness}

The forces behind liability of foreignness are sociological in nature ${ }^{3}$ and have structural, relational and legitimacy dimensions (Zaheer, 2002). Differences in languages and hence understanding are a major but not exclusive factor (West and Graham, 2004). As firms grow and develop within their home market, both the organization and its employees develop and refine certain skills, structures, practices and routines that reflect their social, cultural, economic and legal environment. Put simply, long-lasting exposure, experience and interaction produce a tailor-made entity to function effectively and efficiently in the home market. This knowledge is largely acquired automatically at minimal extra cost. Substantial parts of these social and cultural laws are causally ambiguous and not codified (Jensen and Szulanski, 2004). These factors make it difficult for foreign competitors to buy, imitate or substitute these capabilities on factor markets. Hence, their liability of foreignness prevents them from achieving the same levels of local embeddedness as their host country rivals. These "rough edges" translate into relative deficits in efficiency and effectiveness (Mezias, 2002a). The visible symptoms of these challenges are more frequent errors, unnecessary risks and delays (Lord and Ranft, 2000). Relying heavily on host country management, staff and resources cannot eradicate the problem. The foreign company always has to put additional energy into balancing host country integration with intra-MNC consistency when communicating, coordinating and monitoring across national and cultural borders (Mezias, 2002a, 2002b).

\section{Liability of foreignness in the innovation process}

The management of innovation projects is generally challenging. Outcomes are typically uncertain and input-output relations are vague, making project management and controlling a strenuous task (Kanter, 1989; Quinn, 1985). Core skills and resources have to be developed, motivated, structured and mobilized. The most critical input for the innovation process is a constant stream of ideas, that has to be systematically structured and prioritized (most prominently discussed under the name of Fuzzy Front End) to increase the quality of the innovation inputs and hence the odds of success (Boeddrich, 2004; Reid and de Brentani, 2004). These structured ideas have to be combined with able individuals (often referred to as champions $^{4}$ ) to develop them into suitable innovation projects. These innovation assets have to be aligned with company goals and resources and put on the right track for the most

Eden and Miller (2004) suggest that the economic dimensions of the costs of doing business abroad should be investigated separately. Our study is not designed to disentangle the economic and sociological roots and effects.

Champions take responsibility for an innovation project and secure organizational resources and support. For a more detailed discussion see for example Schon (1963) and Hauschildt and Kirchmann (2001). 
promising innovation projects. Finally, intelligent project management and controlling is required to reach goals within budgets and schedules to achieve success (Hauschildt, 1994, 2004). In conclusion, we derive three core capacities in managing innovation processes: mobilization, selection and execution.

We argue that the already high demands on information processing at all three stages of the innovation management process make it more susceptible to suffer from liability of foreignness. Corporate culture has been identified as a critical factor for successful innovation activities (van der Panne et al., 2003). We argue that cultural barriers from liability of foreignness should consequently have a negative effect. Besides, foreign firms are not fully integrated into host country knowledge flows from customers, suppliers or regulators (Granovetter, 1985; Zaheer and Mosakowski, 1997). These inputs are crucial ingredients for any successful innovation process. The effects of liability of foreignness are amplified if the knowledge that has to be transferred is tacit and ambiguous while valuable sources of knowledge are difficult to separate from secondary noise (Schmidt and Sofka, 2006). The primary pitfalls may not lie in absorbing enough information but in putting it in an adequate context across cultural, social and linguistic borders. In conclusion, we suggest that due to liability of foreignness companies that perform innovation activities abroad are less likely to mobilize critical resources, experience more frequent errors in choosing promising projects and are less successful in managing and controlling projects. Table 1 summarizes the approach from which we derive our central hypothesis:

Hypothesis: As a result of liability of foreignness, multinational companies in foreign locations are less likely to mobilize the inputs for innovation projects; they are more likely to select the wrong projects and they fail to stay within budgets and schedules more often, compared to firms operating in their home market.

Table 1: Mechanisms behind liability of foreignness in the innovation management process

\begin{tabular}{|l|l|l|l|}
\hline $\begin{array}{l}\text { Stage in innovation } \\
\text { process }\end{array}$ & Core competence & $\begin{array}{l}\text { Effect of liability of } \\
\text { foreignness }\end{array}$ & Symptom \\
\hline Mobilization & $\begin{array}{l}\text { Developing, } \\
\text { structuring, selecting } \\
\text { and motivating crucial } \\
\text { resources }\end{array}$ & $\begin{array}{l}\text { Misjudgments of idea } \\
\text { payoff potentials } \\
\text { and/or resource } \\
\text { availability }\end{array}$ & Neglect \\
\hline Selection & $\begin{array}{l}\text { Aligning company } \\
\text { goals and resources for } \\
\text { prioritization and } \\
\text { optimal project choice }\end{array}$ & $\begin{array}{l}\text { Overestimation of } \\
\text { project payoffs or } \\
\text { underestimation of } \\
\text { necessary inputs }\end{array}$ & Cancellation \\
\hline Execution & $\begin{array}{l}\text { Project management } \\
\text { and controlling }\end{array}$ & $\begin{array}{l}\text { Underestimation of } \\
\text { resource requirements }\end{array}$ & Delay \\
\hline
\end{tabular}




\section{$4 \quad$ Empirical study}

\subsection{Estimation strategy}

Liability of foreignness is not a tangible concept. It cannot be easily observed and survey respondents cannot simply be asked to estimate its extent. Therefore, an indirect approach is required. We follow the comprehensive measurement framework suggested by Mezias (2002a). It demands a firm level analysis with controls for other liabilities, contextual aberrations (e.g. size, age, newness) and domestic companies (which can also be multinational) as the comparison group. Within this framework we will address our research hypothesis by testing the observable symptoms presented in Table 1 by asking: Are foreign firms more likely to neglect, cancel or delay their innovation projects abroad? We will estimate the probability of each of these three decisions separately but simultaneously via a trivariate probit model to make optimal use of the available information (for more methodological details see annex 7.1). We will apply this concept to a market with a well developed innovation infrastructure and established innovation activities from multinational corporations: Germany. According to the World Investment Report, 19.1\% of multinational firms with extensive $R \& D$ expenditures place $R \& D$ activities in Germany, which makes it the $8^{\text {th }}$ most attractive foreign R\&D location in the World (UNCTAD, 2005).

\subsection{Data}

For the empirical part of this analysis we use cross section data from a survey on the innovation activities of German enterprises called the "Mannheim Innovation Panel" (MIP) The survey is conducted annually by the Centre for European Economic Research (ZEW) on behalf of the German Federal Ministry of Education and Research. The methodology and questionnaire used by the survey, which is targeted at enterprises with at least five employees, are the same as those used in the Community Innovation Survey (CIS), conducted every four years by Eurostat. For our analysis we use the 2003 survey, in which data was collected on the innovation activities of enterprises during the three-year period 2000-2002. About 4,500 firms in manufacturing and services responded to the survey and provided information on their innovation activities. ${ }^{5}$ We utilise this data to operationalize the concepts presented above. Additionally, we complemented this dataset with international trade data provided by the OECD (ITCS - International Trade by Commodity Statistics 2003 and TIS - Trade in Services 2004) and data on business R\&D expenditures (ANBERD - R\&D Expenditure in Industry 2003).

The sample was drawn using the stratified random sample technique. A comprehensive non-response analysis of more than 4,000 firms showed no systematic distortions between responding and non-responding firms with respect to their innovation activities. For a more detailed description of the dataset and the survey see Janz et al. (2001) and Rammer et al. (2005). 
We restrict our sample to firms with innovation activities in Germany. ${ }^{6}$ On this basis we generate a dataset of 1,063 company observations for which all variables of our model are available. The actual influence of foreign stakeholders (e.g. foreign management, shareholders, employees) cannot be readily observed. Hence, we rely on a conservative measure for identifying a firm as foreign: ${ }^{7}$ We treat a company located in Germany as foreign if it indicated that it is part of a multinational group with its headquarters abroad. Following this line of reasoning, 102 foreign firms in our sample conduct innovation activities in Germany. The remaining companies will be the control group in all further steps of the analysis. This provision follows the rationale that foreign-controlled firms should be compared with a complete sample of host country companies, not only domestically controlled multinationals (Mezias, 2002a).

\subsection{Variables}

\section{Dependent variables}

Our three dependent variables are binary in nature. We derive them from three direct questions as to whether firms experience barriers in their innovation activities that prevent them from starting at least a single new project (neglect), cause them to abandon at least one (cancel) or seriously delay at least one (overrun). Our firm level perspective necessitates the definition of a common standard ("at least a single one"). One could certainly argue that project data would provide additional insights. However, project setups and boundaries vary significantly across firms, which makes it difficult to draw general conclusions. The limitation on firm-level data should nevertheless be kept in mind when interpreting the results. In the absence of more detailed data we are confident that our conceptualization provides adequate, conservative measurement.

\section{Independent variables}

The dummy variable indicating whether a company is foreign-controlled or not ("part of a multinational group with headquarters abroad") is the cornerstone of our analysis. Our hypothesis from section 3 will be supported if the coefficients for this dummy variable are positive and significant in all three equations (neglect, cancel, overrun).

To ensure the reliability of this measurement of liability of foreignness we have to control for the effects from other liabilities (e.g. size, age/newness) and contextual aberrations (Mezias, 2002a). Addressing the former we control for regional effects (whether a company is

$6 \quad$ The dataset also includes firms without innovation activities if they indicated that they refrained from carrying out or cancelled innovation projects.

Zaheer and Mosakowski (1997) discuss several concepts: nationality of the majority of workers, share of foreign shareholders, nationality of the largest single shareholder, perception of a company in a particular country, location of international headquarters. 
located in Eastern Germany and hence the particular German effect of reunification), company age ${ }^{8}$ and firm size (measured by the number of employees in logs).

To avoid contextual aberrations we introduce control variables for a firm's position ${ }^{9}$ in productivity (turnover per employee), export intensity (share of turnover with exports), profitability ${ }^{10}$ and R\&D intensity (R\&D expenditure as a share of turnover). The latter has often been used to measure not only a firm's knowledge intensity but also its absorptive capacities (Cohen and Levinthal, 1989). Absorptive capacities have been found to be subject to liability of foreignness (Schmidt and Sofka, 2006). Hence, we supplement this construct by adding a direct measurement for the exploitive aspects of absorptive capacity: ${ }^{11}$ a dummy variable indicating whether the firm was able to translate impulses from customers, suppliers, competitors or academia into successful innovation. Finally, firm culture and strategy have been identified as important determinants of success in innovation activities (van der Panne et al., 2003). We address the former through a combined index of the importance of innovation incentives and stimulation (e.g. monetary incentives), the latter through a combined index for the importance of innovation strategies (e.g. technology leadership). A detailed description of the indices and their construction can be found in annex 7.3.

Looking beyond the firm level, business expenditures on R\&D have been found to present important signals for foreign R\&D engagements (Feinberg and Gupta, 2004). We control for this effect by adding the share of Germany in OECD R\&D expenditures per industry ${ }^{12}$ and the revealed comparative advantage (RCA) per industry 2002 as a measure for competitive

$8 \quad$ Conceptually this control component should cover the effects from liabilities of age/newness. We have no explicit information in our dataset on when the German company became foreign-controlled and if it was originally founded by the foreign parent company or acquired. We address this issue through two separate concepts. We include the company's age since foundation assuming that older companies have higher reputations and are more deeply rooted in local networks. Additionally, we add a dummy variable indicating whether the company has been involved in substantial (more than 10\% change in turnover) M\&A activities since 2000. The latter should help us to control for dynamics introduced through firm acquisitions.

We use lagged values for 2001 which can be considered predetermined. This allows us to achieve more clarity in differentiating between causes and effects (endogeneity).

The specific design of the profitability question in our survey (ordinal scale) requires the introduction of two respective dummy variables. One dummy variable indicates whether a firm had a negative return on investment, a separate one captures whether a firm had a return on investment above $4 \%$.

Absorptive capacity comprises identifying, assimilating and exploiting external pieces from the environment for innovation (Cohen and Levinthal, 1989, 1990). database. 
performance. ${ }^{13}$ Besides, to control for basic differences in technology we introduce industry dummies. $^{14}$

\subsection{Descriptive statistics}

In this section we highlight major patterns in the variables presented before. A complete list of means and standard errors can be found in Table 4 of the annex. Roughly ten percent of the firms in our sample are foreign-controlled. They are on average not more likely to neglect innovation projects (42\%) than their German counterparts (40\%). Then again, they are typically more likely to cancel ( $41 \%$ vs. $25 \%$ ) or delay projects ( $70 \%$ vs. $50 \%$ ). Hence, a prima facie comparison partly supports our hypothesis on the effects of liability of foreignness.

However, these trends could also be attributed to other differences in firm characteristics. Most importantly, foreign-controlled firms are on average four times larger in terms of employment than the German ones. They are also more profitable, productive and exportoriented, but have lower $R \& D$ intensities. This might be due to the fact that they are more engaged in stimulating innovation activities and formulating demanding innovation strategies. Interestingly, the foreign-controlled firms are typically older but more frequently involved in M\&A activities. In conclusion, a multivariate analysis is warranted.

13 We formulate it in logarithmic terms yielding continuous, unbound and symmetric results (Wolter, 1977).

14 These industry groups are more broadly defined as "other”, "medium high-tech" and "high-tech" manufacturing, and "distributive”, "knowledge-intensive” and "technological” services. The base group in all cases is "other” manufacturing. 


\section{$5 \quad$ Results}

Table 2 presents our estimation results. They provide differentiated support for the hypothesis of our analytical framework. We find that liability of foreignness is not a significant hurdle for foreign-controlled firms when they have to develop and mobilize ideas and skillsets for starting new innovation projects. In the selection and execution stages, though, they are more likely to make suboptimal project choices (which translate into subsequent cancellations) and delay projects. Apparently, the pitfalls from liability of foreignness materialize as ideas have to be combined with resources to form projects. We suspect that resource planning and management in foreign-controlled firms follows templates which are deeply influenced by experience and practice of the multinational company as a whole. These may not readily fit into the local context and the frictional losses from this liability of foreignness surface as more frequent errors and delays. We will return to this theme when deriving conclusions in the following sections.

Table 2: Estimation results of trivariate probit estimation: Parameter estimates (robust standard errors in parentheses)

\begin{tabular}{lccc}
\hline \hline \multicolumn{1}{c}{ Variable } & Neglect & Cancel & Overrun \\
\hline $\begin{array}{l}\text { Company is part of foreign group with headquarters } \\
\text { abroad (dummy) }\end{array}$ & 0.01 & $0.29^{* *}$ & $0.29^{*}$ \\
& $(0.14)$ & $(0.14)$ & $(0.15)$
\end{tabular}

\section{Control variables}

East Germany (dummy)

Company age since foundation (in years)

Company was part of M\&A activities from 2000

with a minimum impact of $10 \%$ of turnover

(dummy)

No of employees (logarithm)

Turnover per employee in 2001

Export share of turnover in 2001 (\%)

Negative return on turnover in 2001 (dummy)

Return on turnover above 4\% in 2001 (dummy)

R\&D intensity in 2001 (\%)

No of employees with higher education normalized by industry average 2001 (ratio)

$\begin{array}{ccc}-0.23 * * * & -0.31 * * * & -0.30^{* * *} \\ (0.09) & (0.10) & (0.09) \\ 0.00 & -0.00^{*} & -0.00^{*} \\ (0.00) & (0.00) & (0.00) \\ 0.21 & 0.05 & 0.35^{*}\end{array}$

$(0.18)$

$(0.18)$

0.04

$0.09 * * *$

$0.08 * * *$

(0.03)

$(0.03)$

$(0.03)$

0.12

$0.13^{*}$

0.03

$(0.08)$

$(0.08)$

$(0.09)$

0.00

0.00

$0.01 * * *$

(0.00)

(0.00)

(0.00)

0.19

$0.31^{* *}$

0.16

(0.12)

(0.12)

(0.12)

$-0.21^{* *}$

0.02

0.02

(0.09)

(0.09)

(0.09)

$0.02^{* * *}$

$-0.00$

0.00

(0.00)

(0.01)

(0.01)

$-0.03$

0.06

0.00 


\begin{tabular}{|c|c|c|c|}
\hline Variable & Neglect & Cancel & Overrun \\
\hline \multirow{2}{*}{$\begin{array}{l}\text { Successful innovation impulses from customers, } \\
\text { suppliers, competitors or academia (dummy) }\end{array}$} & -0.11 & $-0.19 * *$ & 0.19 \\
\hline & $(0.09)$ & $(0.09)$ & $(0.09)$ \\
\hline \multirow{2}{*}{$\begin{array}{l}\text { Index of importance of methods of stimulating } \\
\text { innovation activities (index) }\end{array}$} & 0.04 & 0.02 & $0.41^{*}$ \\
\hline & $(0.23)$ & $(0.24)$ & $(0.24)$ \\
\hline \multirow[t]{2}{*}{ Index of importance of innovation strategies (index) } & $-0.60 * * *$ & -0.31 & 0.06 \\
\hline & $(0.22)$ & $(0.24)$ & $(0.23)$ \\
\hline \multirow{2}{*}{$\begin{array}{l}\text { Germany's revealed comparative advantage } \\
\text { (logarithm) }\end{array}$} & -0.00 & -0.00 & 0.00 \\
\hline & $(0.00)$ & $(0.00)$ & $(0.00)$ \\
\hline \multirow{2}{*}{$\begin{array}{l}\text { German share of global business R\&D expenditures } \\
\text { (\%) }\end{array}$} & 0.00 & $0.01^{* *}$ & -0.00 \\
\hline & $(0.01)$ & $(0.01)$ & $(0.01)$ \\
\hline \multirow[t]{2}{*}{ Medium-high-tech manufacturing (dummy) } & $0.21 *$ & 0.04 & 0.13 \\
\hline & $(0.12)$ & $(0.13)$ & $(0.13)$ \\
\hline \multirow[t]{2}{*}{ High-tech manufacturing (dummy) } & $0.25 *$ & 0.08 & $0.41 * * *$ \\
\hline & $(0.14)$ & $(0.15)$ & $(0.15)$ \\
\hline \multirow[t]{2}{*}{ Distributive services (dummy) } & 0.17 & -0.18 & -0.12 \\
\hline & $(0.17)$ & $(0.19)$ & $(0.17)$ \\
\hline \multirow{2}{*}{ Knowledge-intensive services (dummy) } & $0.43^{* * *}$ & $0.29 * *$ & $0.38 * *$ \\
\hline & $(0.16)$ & $(0.17)$ & $(0.16)$ \\
\hline \multirow[t]{2}{*}{ Technological services (dummy) } & $0.41^{* * *}$ & 0.14 & $0.42 * * *$ \\
\hline & $(0.13)$ & $(0.13)$ & $(0.13)$ \\
\hline \multirow[t]{2}{*}{ Constant } & $-0.33 *$ & $-1.00 * * *$ & $-0.82 * * *$ \\
\hline & $(0.19)$ & $(0.20)$ & $(0.19)$ \\
\hline \multirow[t]{2}{*}{ rho } & $(1 / 2) 0.59 * * *$ & $(2 / 3) 0.52 * * *$ & $(1 / 3) 0.48 * * *$ \\
\hline & $(0.04)$ & $(0.05)$ & $(0.04)$ \\
\hline Observations & & 1,063 & \\
\hline Wald chi ${ }^{2}(60)$ & & 214.31 & \\
\hline Prob $>\operatorname{chi}^{2}(60)$ & & 0.00 & \\
\hline Loglikelihood & & $-1,790.60$ & \\
\hline Aldrich Nelson Pseudo R2 & & 0.23 & \\
\hline
\end{tabular}

* significant at $10 \%$; ${ }^{* *}$ significant at $5 \% ; * * *$ significant at $1 \%$; robust standard errors in parentheses

On the methodological side we find our suggested approach of separate but simultaneous estimation supported. The correlations (rho) between the three error terms are positive and significant. Hence, estimating the three equations as a system is clearly superior to three separate estimations.

All other items in our estimation are primarily motivated as control variables without a priori hypotheses on outcomes. A more extensive discussion of these items can be found in Annex 7.2. Generally speaking, we identify two major forces behind neglected, cancelled or delayed projects. On the one hand, external pressures force companies to streamline their project portfolio. On the other hand, an abundance of potential projects requires prioritisation and concentration on core projects. 
In this paper we focus our attention on how multinational companies can optimize their foreign innovation activities. The latter have been identified as a major vehicle for subsidiary evolution and thus as a cornerstone of MNC competitiveness. We find that foreign innovation engagements do not stumble at the mobilization stages, but rather when projects have to be selected, planned and managed.

One might argue that the courage to cancel failing projects is not a negative organizational trait at all. Pulling the plug on failing projects activates scarce resources and employees may still draw valuable lessons from it. Hence, the tendency to cancel foreign innovation activities more frequently may just be the result of consistent project accounting. The more frequent project delays, though, spoil this argumentation and make us turn to another explanation. We argue that multinational companies have no problems in spotting worthwhile innovation impulses abroad. The effects from a lack of local embeddedness kick in once these ideas have to be prioritized and aligned with resources. We suspect that project priorities and resource planning follow general guidelines of the multinational corporation. These shared procedures provide consistency within the MNC but limit the flexibility of foreign subsidiaries to bring their innovation initiatives fully in line with host country best practices. As a result they are more often forced to recalibrate projects or necessary resources.

Luo et al. (2002) suggest more generally that liabilities of foreignness can be mitigated through offensive (local immersion) or passive strategies (reserve). We argue that only the former is a suitable option in innovation activities that rely heavily on interfirm and interpersonal relationships. Hence, we derive three central recommendations for the innovation management of foreign subsidiaries. With respect to tackling project delays we opt for external, host country expertise in resource planning and accounting to achieve more realistic and tailor-made budgeting/scheduling. The project selection issue is more challenging since it is less suitable for outsourcing. We argue that foreign subsidiaries should actively encourage host country feedback on their innovation projects. This can be achieved by outlining and discussing broader innovation roadmaps for the future, active engagement in local technological networks or host country competitor reconnaissance and evaluation. Finally, we suggest that foreign subsidiaries may streamline their innovation activities by benchmarking their innovation processes with host country, not MNC, counterparts. The MNC does not need "one size fits all” subsidiaries across the world, but perfectly fitted beachheads that plug into local innovation systems and get the most out of them for the better of the whole MNC.

Our analysis faces certain limitations which may in turn provide valuable roads for further research. As mentioned before, a project-level analysis may provide more targeted results if the heterogeneity in project delimitation across company lines can be overcome. What is more, offshoring R\&D activities is mostly discussed with the destinations China and India. With Germany we focused on an important hub in innovation activities with established 
foreign links. We expect the effects of liability of foreignness in developing countries to be even more pronounced. Hence, we consider comparative analysis very promising. 


\subsection{Econometric model and method}

The occurrences of neglected, cancelled or delayed innovation projects are not independent of one another. It is quite conceivable that firms experience all of them at the same time or none at all (we found some of these cases in the data). To model this link between the three events adequately, we use a trivariate probit model instead of estimating the equations separately for each decision. ${ }^{15}$ Within our empirical framework, the trivariate probit is superior to multinomial logit models since it allows us to reflect simultaneous multiple-event occurrence. The trivariate probit model is directly derived from the standard probit model, but allows more than one equation with correlated disturbances. This technique is comparable to the seemingly unrelated regressions model. Estimating three equations simultaneously allows us to improve the estimated sampling precision and subsequently facilitates a more complete usage of the available information. In essence, each probit equation holds information on factors that influenced the decisions on all three options. Estimating these equations simultaneously utilises this information for the complete system. The specification for our three-equation model is:

$$
\begin{aligned}
\text { neglect }^{*} & =\beta_{1}^{\prime} x+\varepsilon_{1}, \text { neglect }=1 \text { if neglect }{ }^{*}>0,0 \text { otherwise, } \\
\text { cancel }^{*} & =\beta_{2}^{\prime} x+\varepsilon_{2}, \text { cancel }=1 \text { if } \text { cancel }^{*}>0,0 \text { otherwise, } \\
\text { overrun }^{*} & =\beta_{3}^{\prime} x+\varepsilon_{3}, \text { delay }=1 \text { if delay* }>0,0 \text { otherwise. } \\
\operatorname{Cov}\left(\varepsilon_{1}, \varepsilon_{2}\right) & =\rho_{1} \\
\operatorname{Cov}\left(\varepsilon_{1}, \varepsilon_{3}\right) & =\rho_{2} \\
\operatorname{Cov}\left(\varepsilon_{2}, \varepsilon_{3}\right) & =\rho_{3}
\end{aligned}
$$

where $\mathrm{x}$ is the vector of explanatory variables and $\rho_{k}$ is the correlation between the error terms $\varepsilon_{i}$ of a pair of equations.

Estimating trivariate or more generally multivariate probit regression models using maximum likelihood methods involves some unique challenges. Normal probability distribution functions have to be calculated in the evaluation of probit-model likelihood functions. While algorithms for the bivariate case exist, more highly dimensional normal distributions are still challenging. Hence, we turned to a simulation-based technique: the Geweke-Hajivassiliou-Keane (GHK) simulator. ${ }^{16}$ This simulator relies on sequentially

$15 \quad$ On this topic see Greene (1993).

16 The GHK simulator is part of the triprobit procedure in the STATA statistical software package. The GHK simulation method has been found to be one of the best simulators for empirical problems based on multivariate normal distributions (Hajivassiliou et al., 1996) 
conditioned, univariate normal distribution functions, through which multivariate normal distribution functions can be expressed.

\subsection{Discussion of control variable results}

We develop no a priori hypotheses for the control variables presented in Table 2. Hence, the discussion of their outcomes is explorative and extends the analytical scope of this paper. We identify two primary streams behind neglected, cancelled or delayed projects. Firstly, pressures from the environment force companies to narrow their project focus. Secondly, too much prospective project impulses propel prioritisation and concentration. Both themes appear in a following detailed discussion.

With respect to other liabilities we find an interesting regional effect in East Germany. Innovation processes there appear to run smoother across the board. Given that the bulk of innovation activity is still concentrated in the Western part of the country ${ }^{17}$, the smaller number of innovation projects in East Germany appears to be more focused and better planned which translates into fewer problems, albeit on a low overall level. Besides, we identify some signs of liability of newness, as firms become less likely to cancel and delay projects as they mature and gain experience. If companies are involved in M\&A activities they become more prone to exceeding project schedules. We suspect that post-M\&A integration efforts diverge project resources. Focussing on the effects of firm size, we caution that this cannot be readily explained as liability of size. Our item of observation is the firm and we ask companies whether they have cancelled or delayed at least one project. Large firms can be assumed to have more innovation projects and are therefore simply more likely to cancel or delay at least one project than a smaller firm with very few projects.

The positive effect of productivity on the likelihood of canceling projects might be explained by the general capability of productive firms to weed out lagging projects through superior accounting techniques. Focusing on export intensity, we suspect that firms that have to provide customer responsiveness across national and cultural borders face incalculable risks that impair exact project planning and result in budget overruns (Schmidt and Sofka, 2006; Sofka and Zimmermann, 2005). For profitability we find a predictable relationship between company success and future investments: Negative results propel cost reductions and hence project cancellations, while higher profits enable some slack investment in projects that would otherwise have been shelved.

R\&D intensity and external innovation impulses are strongly linked to absorptive capacity. If companies bring more ideas into their company they will probably also be more likely to set priorities and neglect certain initiatives with lower importance. Then again, this mechanism of external feedback increases the quality of project choice and translates therefore into lower odds of project cancellation. New projects are typically an important part of ambitious innovation strategies which explains the lower levels of restraint in project starts.

$17 \quad$ Innovation expenditures in East German manufacturing were 5.2 bn $€$ in 2004, out of 75.3 bn $€$ German manufacturing total (Aschoff et al., 2006). 
With an eye on industry variables we find that a more knowledge and technology dynamic environment produces more project options. Firms have to set priorities and therefore neglect certain projects. What is more, the projects in these fields are less predictable in terms of outcomes and necessary resources. Increased rates of project cancellation and/or delays are the result.

\subsection{Construction of strategy and stimulation indices}

Both indices are created through two separate principal factor analyses and varimax rotations. The results strongly indicate a single factor respectively (Table 3).

Table 3: Quality of factor analysis

\begin{tabular}{|l|l|l|l|}
\hline Index & $\begin{array}{l}\text { Eigenvalue 1 } \\
\text { (all } \text { factor }\end{array}$ & $\begin{array}{l}\text { Cronbach's alpha: } \\
\text { Scale reliability } \\
\text { coefficient }\end{array}$ & $\begin{array}{l}\text { Average interitem } \\
\text { covariance }\end{array}$ \\
\hline Strategy & 5.697 & 0.937 & 0.762 \\
\hline Stimulation & 5.879 & 0.943 & 0.633 \\
\hline
\end{tabular}

The index variables that entered the estimation model are the factor loadings rescaled between zero and one. The factor items are the survey responses on a four-point scale of importance to the following components:

\begin{tabular}{|l|l|}
\hline Strategy & Stimulation \\
\hline Technological leadership & Target setting \\
\hline Cost leadership & Strengthening key personnel \\
\hline Industry leader with new products & Talent recruiting/development \\
\hline Industry leader with new processes & Strengthening line managers \\
\hline Introduction of unprecedented technologies & Financial incentives \\
\hline Following competitors & Non-financial incentives \\
\hline Solutions for individual customers & Incentives for idea creation \\
\hline Specialization on niche markets & Groupwork \\
\hline Strategic alliances & Union involvement \\
\hline
\end{tabular}

\subsection{Industry breakdown}

\begin{tabular}{|l|l|l|}
\hline Industry & NACE Code & Industry Group \\
\hline Mining and quarrying & $10-14$ & Other manufacturing \\
\hline Food and tobacco & $15-16$ & Other manufacturing \\
\hline Textiles and leather & $17-19$ & Other manufacturing \\
\hline Wood / paper / publishing & $20-22$ & Other manufacturing \\
\hline Chemicals / petroleum & $23-24$ & $\begin{array}{l}\text { Medium high-tech } \\
\text { manufacturing }\end{array}$ \\
\hline Plastic / rubber & 25 & Other manufacturing \\
\hline Glass / ceramics & 26 & Other manufacturing \\
\hline Metal & $27-28$ & Other manufacturing \\
\hline $\begin{array}{l}\text { Manufacture of machinery and } \\
\text { equipment }\end{array}$ & 29 & $\begin{array}{l}\text { Medium high-tech } \\
\text { manufacturing }\end{array}$ \\
\hline $\begin{array}{l}\text { Manufacture of electrical } \\
\text { machinery }\end{array}$ & $30-32$ & High-tech manufacturing \\
\hline
\end{tabular}




\begin{tabular}{|l|l|l|}
\hline Industry & NACE Code & Industry Group \\
\hline $\begin{array}{l}\text { Medical, precision and optical } \\
\text { instruments }\end{array}$ & 33 & High-tech manufacturing \\
\hline Manufacture of motor vehicles & $34-35$ & $\begin{array}{l}\text { Medium high-tech } \\
\text { manufacturing }\end{array}$ \\
\hline $\begin{array}{l}\text { Manufacture of furniture, } \\
\text { jewellery, sports equipment and } \\
\text { toys }\end{array}$ & $36-37$ & Other manufacturing \\
\hline Electricity, gas and water supply & $40-41$ & Other manufacturing \\
\hline Construction & 45 & Other manufacturing \\
\hline Retail and motor trade & 50,52 & Distributive services \\
\hline Wholesale trade & 51 & Distributive services \\
\hline $\begin{array}{l}\text { Transportation and } \\
\text { communication }\end{array}$ & $60-63,64.1$ & Distributive services \\
\hline Financial intermediation & $65-67$ & $\begin{array}{l}\text { Knowledge-intensive } \\
\text { services }\end{array}$ \\
\hline Real estate activities and renting & $70-71$ & Distributive services \\
\hline ICT services & $72,64.2$ & Technological services \\
\hline Technical services & $73,74.2,74.3$ & Technological services \\
\hline Consulting & $74.1,74.4$ & $\begin{array}{l}\text { Knowledge-intensive } \\
\text { services }\end{array}$ \\
\hline Other business-oriented services & $74.5-74.8,90$ & Distributive services \\
\hline
\end{tabular}

\subsection{Descriptive statistics}

Table 4: Means of model variables (standard errors in parentheses)

\begin{tabular}{lccc}
\hline \multicolumn{1}{c}{ Variable } & Total & Domestic & Foreign \\
\hline No of observations & 1,063 & 961 & 102 \\
Company refrained from at least one innovation & 0.40 & 0.40 & 0.42 \\
project (dummy) & & & \\
& $(0.49)$ & $(0.49)$ & $(0.5)$ \\
Company cancelled at least one innovation project & 0.27 & 0.25 & 0.41 \\
(dummy) & & & \\
& $(0.44)$ & $(0.43)$ & $(0.49)$ \\
Company delayed at least one innovation project & 0.51 & 0.50 & 0.70 \\
seriously (dummy) & & & \\
& $(0.5)$ & $(0.5)$ & $(0.46)$ \\
East Germany (dummy) & 0.34 & 0.35 & 0.25 \\
& $(0.47)$ & $(0.48)$ & $(0.44)$ \\
Company age since foundation (in years) & 18.75 & 18.24 & 23.50 \\
& $(21.13)$ & $(20.85)$ & $(23.14)$ \\
Company was part of M\&A activities since 2000 & 0.05 & 0.05 & 0.09 \\
with a minimum impact of 10\% of turnover & & & \\
(dummy) & & $(0.21)$ & $(0.29)$ \\
& $(0.22)$ & 439.71 & $1,821.24$ \\
No of employees & 572.27 & $(2,806)$ & $(10,455)$ \\
& $(4,204)$ & 0.31 & 0.55 \\
Turnover per employee in 2001 & 0.33 & $(0.49)$ & $(0.87)$ \\
Export share of turnover in 2001 (\%) & $(0.54)$ & 17.29 & 38.35 \\
& 19.31 & $(23.39)$ & $(31.81)$
\end{tabular}




\begin{tabular}{|c|c|c|c|}
\hline Variable & Total & Domestic & Foreign \\
\hline Negative return on turnover in 2001 (dummy) & $\begin{array}{c}0.16 \\
(0.37)\end{array}$ & $\begin{array}{c}0.17 \\
(0.37)\end{array}$ & $\begin{array}{c}0.12 \\
(0.32)\end{array}$ \\
\hline Return on turnover above 4\% in 2001 (dummy) & $\begin{array}{l}0.46 \\
(0.5)\end{array}$ & $\begin{array}{l}0.45 \\
(0.5)\end{array}$ & $\begin{array}{l}0.53 \\
(0.5)\end{array}$ \\
\hline R\&D intensity in 2001 (\%) & $\begin{array}{c}5.09 \\
(10.45)\end{array}$ & $\begin{array}{c}5.25 \\
(10.83)\end{array}$ & $\begin{array}{c}3.57 \\
(5.51)\end{array}$ \\
\hline $\begin{array}{l}\text { Share of employees with higher education in } 2001 \\
\text { (\%) }\end{array}$ & $\begin{array}{r}28.31 \\
(28.56)\end{array}$ & $\begin{array}{r}28.83 \\
(29.07)\end{array}$ & $\begin{array}{r}23.47 \\
(22.76)\end{array}$ \\
\hline $\begin{array}{l}\text { Successful innovation impulses from customers, } \\
\text { suppliers, competitors or academia (dummy) }\end{array}$ & $\begin{array}{c}0.68 \\
(0.47)\end{array}$ & $\begin{array}{c}0.67 \\
(0.47)\end{array}$ & $\begin{array}{c}0.73 \\
(0.45)\end{array}$ \\
\hline $\begin{array}{l}\text { Index of importance of methods of stimulating } \\
\text { innovation activities (index) }\end{array}$ & $\begin{array}{c}0.44 \\
(0.19)\end{array}$ & $\begin{array}{c}0.43 \\
(0.19)\end{array}$ & $\begin{array}{c}0.52 \\
(0.19)\end{array}$ \\
\hline Index of importance of innovation strategies (index) & $\begin{array}{c}0.49 \\
(0.21)\end{array}$ & $\begin{array}{c}0.48 \\
(0.21)\end{array}$ & $\begin{array}{c}0.58 \\
(0.16)\end{array}$ \\
\hline $\begin{array}{l}\text { Germany's revealed comparative advantage } \\
\text { (logarithm) }\end{array}$ & $\begin{array}{c}17.07 \\
(55.00)\end{array}$ & $\begin{array}{c}17.22 \\
(55.48)\end{array}$ & $\begin{array}{r}15.64 \\
(50.48)\end{array}$ \\
\hline $\begin{array}{l}\text { German share of global business R\&D expenditures } \\
\text { (\%) }\end{array}$ & $\begin{array}{c}9.94 \\
(5.98)\end{array}$ & $\begin{array}{c}9.92 \\
(5.98)\end{array}$ & $\begin{array}{l}10.18 \\
(5.99)\end{array}$ \\
\hline
\end{tabular}




\section{$8 \quad$ References}

Almeida, P. and B. Kogut (1999), Localization of Knowledge and the Mobility of Engineers in Regional Networks, Management Science 45 (7), 905-917.

Almeida, P. and A. Phene (2004), Subsidiaries and Knowledge Creation: The Influence of the Mnc and Host Country on Innovation, Strategic Management Journal 25 (8/9), 847864.

Anand, J. and A. Delios (2002), Absolute and Relative Resources as Determinants of International Acquisitions, Strategic Management Journal 23 (2), 119-134.

Anand, J. and B. Kogut (1997), Technological Capabilities of Countries, Firm Rivalry and Foreign Direct Investment, Journal of International Business Studies 28 (3), 445-465.

Aschoff, B., T. Doherr, B. Ebersberger, B. Peters, C. Rammer and T. Schmidt (2006), Innovation in Germany - Results of the German Innovation Survey 2005, Mannheim.

Bilkey, W.J. and E. Nes (1982), Country-of-Origins Effects on Product Evaluation, Journal of International Business Studies 13 (1), 89-99.

Birkinshaw, J. and N. Hood (1998), Multinational Subsidiary Evolution: Capability and Charter Change in Foreign-Owned Subsidiary Companies, Academy of Management Review 23 (4), 773-795.

Boeddrich, H.-J. (2004), Ideas in the Workplace: A New Approach Towards Organizing the Fuzzy Front End of the Innovation Process, Creativity \& Innovation Management 13 (4), 274-285.

Boschma, R. (2005), Proximity and Innovation: A Critical Assessment, Regional Studies 39 (1), 61-74.

Caves, R.E. (1971), International Corporations: The Industrial Economics of Foreign Investment, Economica 38 (149), 1-27.

Cohen, W.M. and D.A. Levinthal (1989), Innovation and Learning: The Two Faces of R\&D, The Economic Journal 99, 569-596.

Cohen, W.M. and D.A. Levinthal (1990), Absorptive Capacity: A New Perspective on Learning and Innovation, Administrative Science Quarterly 35 (1), 128-153.

DeYoung, R. and D. Nolle (1996), Foreign-Owned Banks in the United States: Earning Market Share or Buying It? Journal of Money, Credit, and Banking 28, 622-636.

Diamantopoulos, A., B.B. Schlegelmilch and J.P. Du Preez (1995), Lessons for Pan-European Marketing? The Role of Consumer Preferences in Fine-Tuning the Product-Market Fit, International Marketing Review 12 (2), 38-52. 
Eden, L. and S.R. Miller (2004), Distance Matters: Liability of Foreignness, Institutional Distance and Ownership Strategy, Bush School Working Paper No. 404.

Feinberg, S.E. and A.K. Gupta (2004), Knowledge Spillovers and the Assignment of R\&D Responsibilities to Foreign Subsidiaries, Strategic Management Journal 25 (8/9), 823845.

Florida, R. (1997), The Globalization of R\&D: Results of a Survey of Foreign-Affiliated R\&D Laboratories in the USA, Research Policy 26 (1), 85-103.

Ghemawat, P. (2001), Distance Still Matters: The Hard Reality of Global Expansion, Harvard Business Review 79 (8), 137-146.

Ghemawat, P. (2003), The Forgotton Strategy, Harvard Business Review 81 (11), 76-84.

Granovetter, M. (1985), Economic Action and Social Structure: The Problem of Embeddedness, American Journal of Sociology 91 (3), 481-510.

Greene, W.H. (1993), Econometric Analysis, New York.

Gulati, R., N. Nohria and A. Zaheer (2000), Strategic Networks, Strategic Management Journal 21 (3), 203-215.

Hajivassiliou, V.A., D.L. McFadden and P. Ruud (1996), Simulation of Multivariate Normal Rectangle Probabilities and Their Derivatives: Theoretical and Computational Results, Journal of Econometrics 72 (1-2), 85-134.

Hasan, I. and W. Hunter (1996), Efficiency of Japanese Multinational Banks in the United States, in: Chen, A. H. (ed.) Research in Finance, Greenwich and London, 157-173.

Hauschildt, J. (1994), Die Innovationsergebnisrechnung - Instrument Des F\&E-Controlling, Betriebs Berater (15), 1-8.

Hauschildt, J. (2004), Innovationsmanagement 3, Munich.

Hauschildt, J. and E. Kirchmann (2001), Teamwork for Innovation - the 'Troika' of Promotors, $R \& D$ Management 31 (1), 41-50.

Hsieh, M.-H. (2004), An Investigation of Country-of-Origin Effect Using Correspondence Analysis: A Cross-National Context., International Journal of Market Research 46 (3), 267-295.

Hymer, S.H. (1976), The International Operations of National Firms: A Study of Direct Investment, Cambridge.

Janz, N., G. Ebling, S. Gottschalk and H. Niggemann (2001), The Mannheim Innovation Panels (Mip and Mip-S) of the Centre for European Economic Research (Zew), Journal of Applied Social Science Studies 121 (1), 123-129. 
Jarillo, J.C. and J.I. Martinez (1990), Different Roles for Subsidiaries: The Case of Multinational Corporations in Spain, Strategic Management Journal 11 (7), 501-512.

Jensen, R. and G. Szulanski (2004), Stickiness and the Adaption of Organizational Practices in Cross-Border Knowledge Transfers, Journal of International Business Studies 35 (6), 508-523.

Kanter, R.M. (1989), Swimming in Newstreams: Mastering Innovation Dilemmas, California Management Review 31 (4), 45-69.

Kuemmerle, W. (1999), The Drivers of Foreign Direct Investment into Research and Development: An Empirical Investigation., Journal of International Business Studies 30 (1), 1-25.

Lord, M.D. and A.L. Ranft (2000), Organizational Learning About New International Markets: Exploring the Internal Transfer of Local Market Knowledge, Journal of International Business Studies 31 (4), 573-589.

Luo, Y., O. Shenkar and M.-K. Nyaw (2002), Mitigating Liabilities of Foreignness: Defensive Versus Offensive Approaches, Journal of International Management 8 (3), 283-301.

Mezias, J.M. (2002a), How to Identify Liabilities of Foreignness and Assess Their Effects on Multinational Corporations., Journal of International Management 8 (3), 265-283.

Mezias, J.M. (2002b), Identifying Liabilities of Foreignness and Strategies to Minimize Their Effects: The Case of Labor Lawsuit Judgement in the United States, Strategic Management Journal 23, 229-244.

Miller, S.R. and A. Parkhe (2002), Is There a Liability of Foreignness in Global Banking? An Empirical Test of Banks’ X-Efficiency, Strategic Management Journal 31 (1), 323337.

Petersen, B. and T. Pedersen (2002), Coping with Liability of Foreignness: Different Learning Engagements of Entrant Firms, Journal of International Management 8 (3), 339-350.

Quinn, J.B. (1985), Managing Innovation: Controlled Chaos, Harvard Business Review 63 (3), 73-84.

Rammer, C., B. Peters, T. Schmidt, B. Aschhoff, T. Doherr and H. Niggemann (2005), Innovationen in Deutschland - Ergebnisse Der Innovationserhebung 2003 in Der Deutschen Wirtschaft, Zew Wirtschaftsanalysen 78, Baden-Baden.

Reid, S.E. and U. de Brentani (2004), The Fuzzy Front End of New Product Development for Discontinuous Innovations: A Theoretical Model, Journal of Product Innovation Management 21 (3), 170-184.

Rugman, A.M. and A. Verbeke (2004), A Perspective on Regional and Global Strategies of Multinational Enterprises, Journal of International Business Studies 35 (1), 3-18. 
Schmidt, T. and W. Sofka (2006), Lost in Translation - Empirical Evidence for Liability of Foreignness as Barriers to Knowledge Spillovers, ZEW Discussion Paper No. 06-001, Mannheim.

Schon, D.A. (1963), Champions for Radical New Inventions., Harvard Business Review 41 (2), 77-87.

Sofka, W. and J. Zimmermann (2005), There's No Place Like Home a Strategic Framework to Overcome Liability of Foreignness in the German Car Market, ZEW Discussion Paper No. 05-84, Mannheim.

UNCTAD (2005), World Investment Report 2005, Geneva.

van der Panne, G., C. van der Beers and A. Kleinknecht (2003), Success and Failure of Innovation: A Literature Review, International Journal of Innovation Management 7 (3), 309-338.

Vernon, R. (1966), International Investment and International Trade in the Product Cycle, Quarterly Journal of Economics 80 (May), 190-207.

West, J. and J.L. Graham (2004), A Linguistic-Based Measure of Cultural Distance and Its Relationship to Managerial Values, Management International Review 44 (2), 239260.

Wolter, F. (1977), Factor Proportions, Technology and West-German Industry's International Trade Patterns, Weltwirtschaftliches Archiv No. 113, Tübingen.

Zaheer, S. (1995), Overcoming the Liability of Foreignness., Academy of Management Journal 38 (2), 341-364.

Zaheer, S. (2002), The Liability of Foreignness, Redux: A Commentary, Journal of International Management 8 (3), 351-358.

Zaheer, S. and E. Mosakowski (1997), The Dynamics of the Liability of Foreignness: A Global Study of Survival in Financial Services, Strategic Management Journal 18 (6), 439-464.

Zaheer, S. and A. Zaheer (1997), Country Effects on Information Seeking in Global Electronic Networks, Journal of International Business Studies 28 (1), 77-100. 